Check for updates

London, UK

Cite this as: BMJ 2021;372:n626 http://dx.doi.org/10.1136/bmi.n626 Published: 04 March 2021

\title{
Covid-19: Government pursued in the courts over controversial antibody test
}

\section{Stephen Armstrong}

Legal campaigners have vowed to continue their action against the government over the maladministration of public funds involving a rapid antibody test.

The Good Law Project, a not-for-profit legal organisation, made the pledge following the Department of Health and Social Care's announcement that it has cancelled orders for the controversial testing device. The organisation was behind a high court ruling last month that said the government acted unlawfully in failing to publish contracts awarded without competition during the covid-19 pandemic, such as for personal protective equipment contracts. ${ }^{1}$

In October, the government purchased one million AbC-19 tests from the UK Rapid Testing Consortium (UK-RTC) for use in surveillance studies, used to build up a picture of how the SARS-CoV-2 virus has spread across the country. The contract included provision for the government to buy more tests as long as the test was authorised for home use by the regulator, the Medicines and Healthcare Products Regulatory Agency (MHRA). The consortium is a group of manufacturers led by Abingdon Health and assembled by John Bell, regius professor of medicine at Oxford University and the government's life sciences adviser, in response to a government call last year for a UK antibody test.

The contract, worth a potential $€ 75 \mathrm{~m}$ (€87m; \$105m) in sales, was made without public tender and prompted a legal challenge by the Good Law Project. ${ }^{2}$ The test has since been rejected by the MHRA as a home test, leading the government to cancel further orders in January. It was also subject of a critical evaluation by Public Health England, published in The BMJ, which found that one in five people with positive results on the test could be wrongly told they had covid-19. ${ }^{3}$

Gemma Abbott, legal director of the Good Law Project, told The BMJ, “Government took a huge gamble with public money: one that did not come off. The tests were not fit for their intended purpose. The government may now have cancelled its contract with Abingdon Health, but it continues to resist our legal proceedings. We have long thought the use of emergency procurement procedures directly to award lucrative contracts to Abingdon Health was unlawful. We think the public deserves the truth, and we will continue to pursue this through the courts."

After cancelling any further test orders in January, the department sent the Good Law Project a letter, saying that the health secretary Matt Hancock had "exercised his contractual right to cancel with immediate effect all outstanding orders.” It might still place further orders but there would be competition.

Documents leaked to the Daily Mail ${ }^{4}$ show that decisions were rushed through by ministers and advisers despite warnings from senior civil servants and government lawyers that the deals it signed with Abingdon Health $-£ 2.5 \mathrm{~m}$ for development, £1om for components, and up to $€ 75 \mathrm{~m}$ for supply-were at "high risk" of being ruled unlawful if challenged. The advice appears to have been ignored.

The department said in a statement to The BMJ, "We do not comment on details relating to ongoing legal proceedings, but we have always been clear that government contracts must deliver value for taxpayer money and we will take action in instances where this does not happen."

In a statement, Abingdon said that the company is still manufacturing the tests in anticipation of future orders. "The company completed the delivery of an order of 1 million AbC-19 anti-spike IgG devices to the Department of Health and Social Care on 8 January 2021. The company is continuing to manufacture the AbC-19TM Rapid Test in anticipation of additional orders and to that end Abingdon's regulatory department is currently working with UK-RTC partners on regulatory approval in a total of 27 territories."

The BMJ has also contacted John Bell and Oxford University but, at time of going to press, has received no response.

Dyer C. Covid-19: Hancock's failure to publish contracts was unlawful. BMJ 2021;372:n511. doi: 10.1136/bmi.n511 pmid: 33608255

2 Armstrong S. Covid-19: Government faces legal action over $\mathrm{f} 75 \mathrm{~m}$ contract for antibody tests. BMJ2020;371:m4427. doi: 10.1136/bmj.m4427 pmid: 33184045

3 Mulchandani R, Jones HE, Taylor-Phillips S, et alEDSAB-HOME and COMPARE Investigators. Accuracy of UK Rapid Test Consortium (UK-RTC) "AbC-19 Rapid Test" for detection of previous SARS-CoV-2 infection in key workers: test accuracy study. BMJ 2020;371:m4262.pmid: 33177070

4 Rose D. Ministers ignored legal advice to give failing company a huge covid test contract leaving taxpayers with $\mathrm{f} 87$ million bill when tests didn't work. Daily Mail. 5 February 2021. www.dailymail.co.uk/news/article9229507/Taxpayers-foot-87m-bill-ministers-failing-company-Covid-contract-cancel-it.html?ito=email_share_article-masthead.

This article is made freely available for use in accordance with BMJ's website terms and conditions for the duration of the covid-19 pandemic or until otherwise determined by BMJ. You may use, download and print the article for any lawful, non-commercial purpose (including text and data mining) provided that all copyright notices and trade marks are retained. 